\title{
RELAÇÃO DOS GENES ADH1 E ADH2 COM A TOLERÂNCIA AO ETANOL EM SACCHAROMYCES CEREVISIAE BY4741.
}

\author{
P. S. $\operatorname{COSTA}^{1,2,3}$, L. G. FIETTO 3 \\ ${ }^{1}$ Universidade Estadual de Campinas, Faculdade de Engenharia Química \\ ${ }^{2}$ Centro Nacional de Energias e Materiais \\ ${ }^{3}$ Universidade Federal de Viçosa \\ E-mail para contato: patriciacosta.ufv@gmail.br
}

RESUMO - Tem sido relatado que o etanol produzido durante o processo fermentativo é um forte inibidor do crescimento e produção de massa para as leveduras, e isso está diretamente relacionado com o rendimento do processo. Neste contexto, estudos dos genes ADH1 e $\mathrm{ADH} 2$ relatam que os mesmos estão diretamente envolvidos no processo de fermentação, aumentando a tolerância de Saccharomyces cerevisiae ao produto de fermentação. A fim verificar tal fato, este trabalho teve como objetivo confirmar a relação desses genes com a tolerância ao etanol na levedura $S$. cerevisiae BY4741. Para isso foi realizada a comparação do perfil de crescimento da levedura $S$. cerevisiae BY4741 com suas mutantes ADH1 e $\mathrm{ADH} 2$ deletado, com relação à tolerância a etanol. Foi feito também, a confirmação dos mutantes usando a técnica de PCR. Os resultados nos leva a concluir que os genes ADH1 e ADH2 realmente estão relacionados com a tolerância ao etanol na levedura $S$. cerevisiae BY4741.

\section{INTRODUÇÃO}

A limitação da oferta de combustíveis fósseis e o fortalecimento das políticas de desenvolvimento sustentável, ganha especial atenção o etanol obtido a partir do bagaço de cana de açúcar, resíduo abundante na indústria sucroalcooeira. Neste sentido, tem sido demonstrado que maiores rendimentos em etanol são obtidos por meio do processo de sacarificação e fermentação simultânea (SSF) do bagaço de cana-de-açúcar (Tomás-Pejó, 2008). Um fator importante que afeta a produtividade do processo é a toxidade de vários fatores químicos e físicos oriundos dos substratos a serem fermentados ou produzidos durante a fermentação tais como o etanol, que limitam consideravelmente a obtenção de massa celular e os bons rendimentos do processo (Trabalzini et al., 2003; Wu et al., 2006). Neste contexto, estudos dos genes ADH1 e ADH2 relatam que os mesmos estão diretamente envolvidos no processo de fermentação, aumentando a tolerância de S. cerevisiae ao produto de fermentação (Trabalzini et al., 2003). A fim de direcionar estratégias de engenharia metabólica visando o melhoramento da capacidade fermentativa destas cepas, este trabalho teve como objetivo confirmar a relação desses genes com a tolerância ao etanol na levedura Saccharomyces cerevisiae BY4741. Para isso foi realizada a caracterização e a comparação do perfil de crescimento da levedura $S$. cerevisiae BY4741 com suas mutantes ADH1 e ADH2 deletado, com relação à tolerância a etanol. A caracterização foi realizada avaliando o perfil de crescimento dessas leveduras em meio e liquido em presença de diferentes concentrações de 
etanol, utilizando micro cultivos. Foi feito também, a confirmação dos mutantes usando a técnica de PCR.

\section{MATERIAIS E MÉTODOS}

\subsection{Avaliação da tolerância a etanol}

Ensaios de tolerância ao etanol foram realizados em microplacas de 96 poços, incubadas sob agitação. As leveduras foram previamente crescidas em meio YPD $2 \%$, em frascos de $50 \mathrm{~mL}$ utilizando um volume de trabalho de $20 \mathrm{~mL}$, sob agitação de $180 \mathrm{rpm}$ a $28{ }^{\circ} \mathrm{C}$. A partir deste pré-inoculo foram feitas diluições em solução salina para que a D.O $(600 \mathrm{~nm})$ inicial, para ser aplicada $10 \mu \mathrm{L}$ desta num volume de $200 \mu \mathrm{L}$ de cultivo, para que começasse com a D.O 0,1. Cada levedura foi inoculada em condições específicas na microplaca, sendo que o volume final do meio foi $200 \mu \mathrm{l}$ e cada ensaio foi feito em triplicata. Os testes foram feitos variando as concentrações de etanol (etanol 0, 2, 4, 6 e $8 \%$ em YPD $2 \%$ ) e um teste para crescimento em YP na presença de $3 \%$ de etanol. As placas foram vedadas usando plástico (Platemaxaxysel sealing film, Axygen) e incubadas na leitora Versamax (microplate reader, Molecular Devices) na temperatura de $30{ }^{\circ} \mathrm{C}$ por 16 horas. O programa SoftMax Pro 5.3 foi utilizado pelo computador e acoplado à leitora Versamax com as seguintes programações: Comprimento de onda $(\lambda)$ para as leituras de densidade ótica: $600 \mathrm{~nm}$; Pré-leitura da placa vazia na D.O (600 nm); Tempo da curva de crescimento: 16 horas; Temperatura de incubação definida: $30^{\circ} \mathrm{C}$; Leituras da D.O $(600 \mathrm{~nm})$ : a intervalos de 15 minutos; Agitação da placa: 5 segundos antes da leitura e 5 segundos entre as leituras. Deste modo ao fim de 16 horas os dados coletados do cultivo foram transferidos para o programa EXCEL e foram confeccionados os gráficos.

\section{2 - Identificação dos mutantes}

\subsection{1 - Extração do DNA total}

Para extração do DNA total, uma alçada de cada levedura em questão foi incubada em tampão de lise (50 mL de Tris-HCl 1M, pH 8,0; $10 \mathrm{~mL}$ de EDTA 0,5 M, pH 8,0; $20 \mathrm{~mL}$ de NaCl $5 \mathrm{M}$; $50 \mathrm{~mL}$ de SDS a $10 \%(\mathrm{p} / \mathrm{v})$ a $65^{\circ} \mathrm{C}$ por um tempo mínimo de 30 minutos. Após este período foi adicionado $100 \mu \mathrm{l}$ de fenol:clorofórmio:isopropílico na proporção $25: 24: 1$, a amostra foi agitada vigorosamente por 3 minutos e submetida à centrifugação a $6.000 \mathrm{~g}$ por 15 minutos. Em seguida, o sobrenadante foi transferido para outro tubo e foi adicionado um volume de $100 \mu \mathrm{l}$ de etanol $70 \%$ gelado. A amostra foi homogeneizada por inversão e novamente submetida a centrifugação a 6.000 g por 3 minutos. O sobrenadante foi descartado e o tubo contendo o DNA genômico foi deixado a temperatura ambiente secando por 16 horas. A amostra foi ressuspendida em $100 \mu 1$ de tampão TE pH 8,0 (10 mL de Tris-HCL1 M, pH 8,0; $2 \mathrm{~mL}$ de EDTA $0,5 \mathrm{M}, \mathrm{pH} 8,0)$. A integridade do DNA genômico foi avaliada em gel de agarose $1 \%(\mathrm{p} / \mathrm{v})$ em tampão TBE (54 g de tris-base; $27,5 \mathrm{~g}$ de ácido bórico; $20 \mathrm{~mL}$ de EDTA $0,5 \mathrm{M}, \mathrm{pH} 8,0)$. O gel foi corado com solução de brometo de etídio e visualizado sob luz ultravioleta. 


\subsection{2 - Amplificação utilizando os iniciadores ADH1, ADH2 e Kam}

A reação de PCR (reação em cadeia da polimerase) foi realizada em um volume final de 20 $\mu 1$, utilizando a Taq DNA Polymerase Fermentas e 10 pmoles dos iniciadores (SIGMA), segundo (Rosa e Lachance, 1998):

ScADH1 F: (5'-GAATTCCTTCCTTCCAGTTACTTGAATTTG-3')

ScADH1 R: (5'-CTCGAGCCTGACCTACAGGAAAGAGTTACTC-3')

ScADH2 F: (5'-GGATCCGCATCTCCAACTTATAAGTTGGAG-3')

ScADH2 R: (5'-CTCGAGGTGAAACTTCGAACACTGTCATC-3')

KanMX F: (5'-TAGGTCTAGAGATCTGTTTAGCTTGCC-3')

KanMX R: (5'-TCGAATCGACAGCAGTATAGCG-3')

A reação de amplificação foi realizada utilizando-se o termociclador PCR Express (Thermo Hybaid). Os produtos de PCR foram analisados em gel de Agarose $1 \%(\mathrm{p} / \mathrm{v})$, conforme descrito anteriormente.

\section{3 - RESULTADOS E DISCUSSÃO}

\section{1 - Avaliação da tolerância a etanol em meio líquido}

Observa-se pelos perfis de crescimento nas diferentes concentrações de etanol, apresentado pela Figura 1 (A, B, C) que a levedura selvagem apresentou melhor tolerância ao etanol comparado com as cepas ADH1 e ADH2 deletados. Observe que a levedura selvagem (Figura $1 \mathrm{~A})$ atingiu a D.O máxima similar ao meio sem etanol até a concentração de $6 \%$ de etanol. Acima de $6 \%$ de etanol a sua D.O máxima, comparada com o meio sem etanol, foi afetada.

Observe que para a cepa ADH2 deletada a presença do etanol afetou a D.O máxima atingida, comparada com o meio sem a presença do etanol (linha azul) (Figura 1 B). Já em $2 \%$ de etanol a D.O máxima foi afetada e assim a medida que foi se aumentando a concentração de etanol (Figura 1 B). Observe que para a cepa ADH1 deletada a presença do etanol afetou a D.O máxima atingida, comparada com o meio sem a presença do etanol (linha azul), a partir de $4 \%$ de etanol (Figura 1 C). Já em $2 \%$ de etanol a D.O máxima não foi afetada, porém em maiores concentrações a D.O máxima atingida foi diminuindo a medida que foi aumentando a concentração de etanol. Porém a D.O máxima foi similar para a concentração de 4 e $6 \%$ de etanol (Figura $1 \mathrm{C}$ ). Percebe-se que a medida que se aumentou a concentração de etanol a fase lag foi prolongada, para todas as três cepas testadas, porém este fato foi mais evidente para as cepas modificadas comparadas com a selvagem (Figura $1 \mathrm{~A}, \mathrm{~B}$ e C). A levedura ADH2 foi a mais afetada pelo stress provocado pelo etanol. O gene ADH2 é responsável pelo consumo do etanol, e isso justifica o fato de apresentar mais stress, pois a mesma perdeu a capacidade de metabolizar o etanol do meio e deixar o ambiente mais propício para o seu crescimento.

Este experimento comprova que os genes $\mathrm{ADH} 1$ e $\mathrm{ADH} 2$ estão de fato relacionado com a tolerância ao etanol, pois as leveduras que possuem esses genes deletados são mais sensíveis ao etanol comparada com a cepa selvagem, onde esses genes estão intactos. Estes resultados estão apresentados como médias das triplicatas dos experimentos, as barras de erros não serão apresentadas devidos os desvios baixíssimos, na ordem de 0,05 . 
Figura 1 - Curva de crescimento das leveduras: A) BY4742; B) $\triangle \mathrm{ADH} 2 \mathrm{BY} 4742$ e C) $\triangle \mathrm{ADH} 1 \mathrm{BY} 4742$. As diferentes composições de meio estão na mesma sequência para as três cepas testadas. Amarelo: meio YPD $2 \%$ adicionado de $2 \%$ de etanol. Vermelho: meio YPD

$2 \%$ adicionado de $4 \%$ de etanol. Cinza: meio YPD $2 \%$ adicionado de $6 \%$ de etanol.

Laranja: meio YPD2\% adicionado de 8\% de etanol. Preto: meio YPD $2 \%$ adicionado de 10 $\%$ de etanol. Verde: meio YP adicionado de $3 \%$ de etanol. Azul: meio YPD $2 \%$ sem a adição de etanol
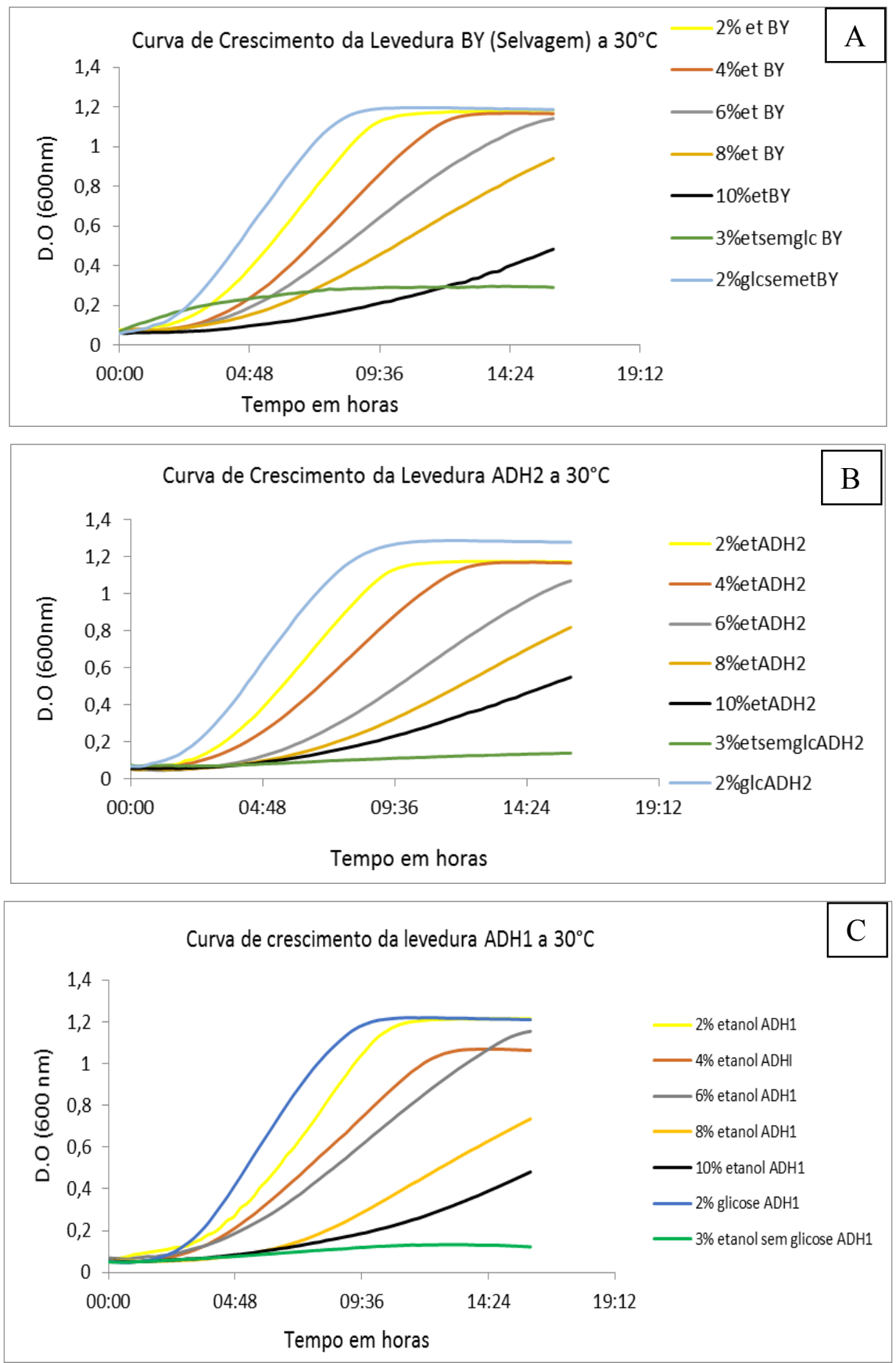


\section{2 - Identificação dos mutantes}

Para poder validar os experimentos e conclusões sobre a influência dos genes ADHs sobre a tolerância ao etanol nas leveduras, foi verificado se realmente as leveduras mutantes estavam mutadas corretamente.

Para isso foi extraído o DNA genômico das leveduras e realizados PCRs usando primeres específicos dos genes ADH1, ADH2 e KanMX.

A Figura 3 mostra o resultado do PCR que foi feito para a confirmação dos mutantes.

Para confirmar a presença da sequência KanMX, que foi trocada no lugar dos genes ADHs, por recombinação homóloga, no genoma das leveduras mutantes, foram realizados PCRs usando os primeres específicos para a sequência do KanMX. Observando a Figura 3 A, resultado do PCR citado acima, pode-se afirmar que a sequência do KanMX está realmente no genoma das leveduras mutantes ADH1 (Figura 2 A, numeração 4) e ADH2 (Figura 2 A, numeração 1) onde ocorreu uma amplificação forte na posição de aproximadamente $1200 \mathrm{pb}$. A numeração 2 da Figura 2A refere-se ao PCR usando os primeres do KanMX e o DNA da levedura selvagem. Como mostra, esta levedura não possui a sequência KanMX em seu genoma, apresentando amplificação somente em algumas regiões inespecíficas, o que era esperado por se tratar de uma levedura selvagem.

Foi confirmada a presença da sequência do KanMX nas leveduras mutantes, resultado demonstrado na Figura 2 A, mas nada se pode falar a respeito da localização desta sequência, não se sabe se a recombinação homóloga foi realmente com os genes ADH1 e ADH2.

Pelo fato dos primeres do gene $\mathrm{ADH} 2$ não estarem funcionando, não tivemos condição de determinar a localização da sequência do KanMX na levedura mutante ADH2.

A determinação da localização da sequência do KanMX na levedura ADH1 foi realizada utilizando combinações de primeres da sequência do KanMX com primeres do gene ADH1, resultados esses, demonstrado na Figura $2 \mathrm{~B}$.

A numeração 1 da Figura $2 \mathrm{~B}$ demonstra o resultado que confirma a presença da sequência KanMX na localização do gene $\mathrm{ADH} 1$. Esse resultado pode ser certificado pela forte amplificação de uma única banda com o tamanho da sequência do KanMX, sendo que foi utilizada a combinação do primer $\mathrm{F}$ do gene $\mathrm{ADH} 1$ com o primer $\mathrm{R}$ do KanMX. A amplificação, vinda desta combinação, confirma que realmente o mutante possui seu gene ADH1 deletado.

A numeração 1 e 2 que representa o resultado do PCR realizado com o DNA das leveduras $\mathrm{ADH} 2$ deletada e a levedura selvagem BY, usando a combinação de primeres descrita abaixo (Figura 2 B). Percebe-se que os padrões de bandas para as duas leveduras foram iguais, sugerindo que sejam bandas inespecíficas já que foi visto que os primeres $\mathrm{ADH} 2$ não estavam funcionando.

Figura 2 - A) Resultado do PCR com uma temperatura de anelamento de $54^{\circ} \mathrm{C}$ corrido em gel de agarose $1 \%$, corado com brometo de etídio. A sequêcia de numeração indica as seguintes combinações de DNA e primeres do PCR: 1- Primeres do KanMX com o DNA da levedura mutante ADH2; 2- Primeres do KanMX com DNA da levedura selvagem BY; 3- Marcador molecular de 500 pb; 4- Primeres do KanMX com DNA da levedura mutante ADH1; 5-

Controle negativo, sem primeres com o DNA da selvagem; 6- Marcador molecular de $500 \mathrm{pb}$.

B) Resultado do PCR com uma temperatura de anelamento de $56^{\circ} \mathrm{C}$ corrido em gel de agarose $1 \%$, corado com brometo de etídio. A sequêcia de numeração indica as seguintes 
combinações de DNA e primeres do PCR: 1- Primer F do gene ADH1 e primer R da sequência do KanMX com o DNA da levedura mutante ADH1; 2- Primer F do gene ADH1 e primer R da sequência do KanMX com o DNA da levedura mutante ADH2; 3- Primer F do gene ADH1 e primer R da sequência do KanMX com o DNA da levedura selvagem BY; 4Controle negativo, primer $\mathrm{F}$ do gene ADH1 e primer R da sequência do KanMX KanMX sem

DNA; 5- Marcador molecular de 500 pb; 6- Primer F e R do gene ADH1 com o DNA da levedura mutante ADH1; 7- Primer F e R do gene ADH1 com o DNA da levedura selvagem BY; 8- Controle negativo, primer F e R do gene ADH1 sem DNA; 9- Marcador molecular de $500 \mathrm{pb}$.
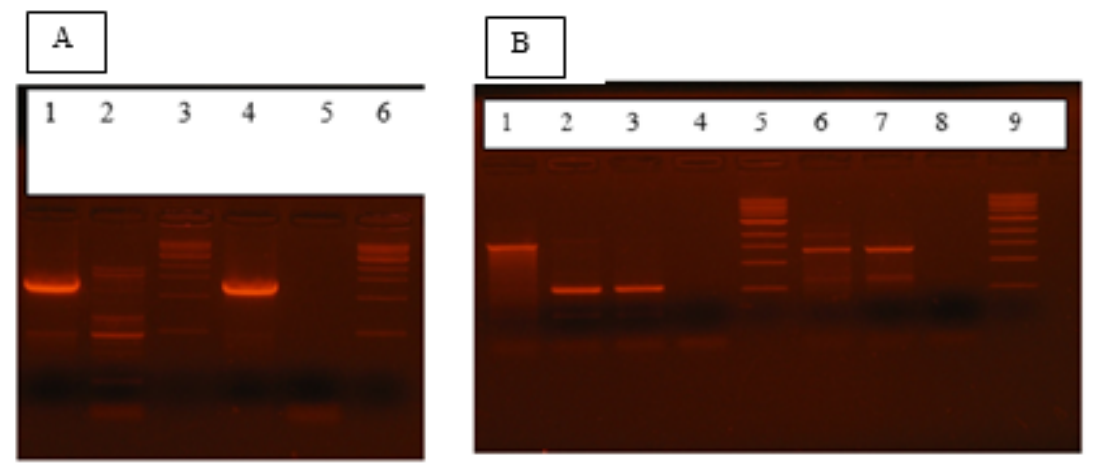

\section{4 - CONCLUSÕES}

Foi verificado que as leveduras mutantes são menos resistentes ao etanol comparado com a levedura selvagem. O que comprova que os genes $\mathrm{ADH} 1$ e $\mathrm{ADH} 2$ realmente estão relacionados com a tolerância ao etanol na levedura Saccharomyces cerevisiae BY4741. A o gene ADH1 está realmente deletado pela sequência KanMX. A mutante ADH2 possui a sequência KanMX inseria no seu genoma, mas não se pode afirmar ainda localização desta sequência pois o primer $\mathrm{ADH} 2$ não estava funcionando.

\section{5 - REFERÊNCIAS}

TOMÁS-PEJÓ, E.; GARCÍA-APARICIO, M.; NEGRO, M. J.; OLIVA, J. M.; BALLESTEROS, M. Effect of different cellulase dosages on cell viability and ethanol productioby Kluyveromyces marxianus in SSF processes. Bioresource Technology; 100: 890-895, 2008.

TRABAlZINI, L., PAFFETTI, A., SCALONI, A., TALAMO, F., FERRO, E., CORATZA, G., BOVALINI, L., LUSINI, P., MARTELLI, P., SANTUCCI, A. Proteomic response to physiological fermentation stresses in a wild-type wine strain of Saccharomyces cerevisiae. Biochem. J. 370, 35-46, 2003.

WU, H., ZHENG, X., ARAKI, Y., SAHARA, H., TAKAGI, H., SHIMOI, H. Global gene expression analysis of yeast cells during sake brewing. Appl. Environ. Microbiol. 72, 7353-7358, 2006. 